\title{
Antimicrobial activity and toxicity of Quisqualis indica
}

\author{
Fatima N Jahan ${ }^{1}$, Mohammad S Rahman ${ }^{2}$, Mahboob Hossain ${ }^{1}$ and Mohammad A Rashid ${ }^{2,3, *}$ \\ ${ }^{1}$ Department of Pharmacy, The University of Asia Pacific, Dhaka-1209, Bangladesh; ${ }^{2}$ Department of \\ Pharmaceutical Chemistry, Faculty of Pharmacy, University of Dhaka, Dhaka-1000, Bangladesh; ${ }^{3}$ Centre for \\ Biomedical Research, University of Dhaka, Dhaka-1000, Bangladesh
}

\begin{abstract}
SUMMARY
The plant Quisqualis indica (Compositae) has ehnopharmcological reputation of being used as a healing agent in Bangladesh. In this study, preliminary screenings were conducted to look at the antimicrobial susceptibility and cytotoxicity of the plant extract. The extractives of the plant were subjected to screening for inhibition of microbial growth by the disc diffusion method. The zones of inhibition demonstrated by the $n$-hexane, carbon tetrachloride, chloroform and aqueous soluble partitionates of the methanolic extract ranged from $8-15 \mathrm{~mm}, 8-18 \mathrm{~mm}, 12-20 \mathrm{~mm}$ and $10-16 \mathrm{~mm}$, respectively at a concentration of $400 \mu \mathrm{g} /$ disc. All the extractives were also subjected to brine shrimp lethality bioassay for primary cytotoxicity evaluation. Here, the carbon tetrachloride soluble materials demonstrated the highest cytotoxicity with $\mathrm{LC}_{50}$ of $0.826 \mu \mathrm{g} / \mathrm{ml}$, while $n$-hexane, chloroform and aqueous soluble partitionates of the methanolic extract revealed the $\mathrm{LC}_{50}$ of $1.254,3.866$ and $5.366 \mu \mathrm{g} / \mathrm{ml}$, respectively. This is the first report of the antimicrobial activity and cytotoxicity $Q$. indica.
\end{abstract}

Key words: Quisqualis indica; Combretaceae; Antimicrobial; Cytotoxicity; Disc diffusion; Brine shrimp lethality

\section{INTRODUCTION}

Medicinal plants have long been the subjects of human curiosity and need. It is estimated that there are about 2,500,000 species of higher plants and the majority of these have not been examined in detail for their pharmacological activities (Ram et al., 2004). The antimicrobial properties of certain Bangladeshi medicinal plants were reported based on folkloric information and a few attempts were made to study the inhibitory activity against certain pathogenic bacteria and fungi (Rashid et al., 1997;

*Correspondence: Mohammad A Rashid, Department of Pharmaceutical Chemistry, Faculty of Pharmacy, University of Dhaka, Dhaka-1000, Bangladesh. Tel: +88028612069, 966190073, Ext, 4363, 4364, 8137; Fax: 88028612069; E-mail: rashidma@aitlbd.net
Rahman et al., 2001). In recent years, multiple drug resistance in human pathogenic microorganisms has developed due to indiscriminate use of commercially available antimicrobial drugs used in the treatment of infectious diseases. This situation forced scientists for searching new antimicrobial substances from medicinal plants, which are the good sources of novel antimicrobial and chemotherapeutic agents (Karaman et al., 2003). One of the aims of the present study was to investigate the antimicrobial susceptibility of different extractives of Quisqualis indica against a wide range of pathogenic bacteria and fungi, which have not been evaluated earlier. Brine shrimp (Artemia salina) larvae have been used for many years in toxicological studies. Many researchers are now using brine shrimp as a prescreen for plant extracts as it provide a quick, 
inexpensive, and desirable alternative to test on larger animals. It is known that a positive correlation exists between brine shrimp lethality and $9 \mathrm{~KB}$ (human nasopharyngeal carcinoma) cytotoxcity; brine shrimp are therefore used in many pre-screens for potential anti-tumor activity (Meyer et al., 1982). In addition, brine shrimp bioassay effectively predicts pesticidal activities and respond to a broad range of chemically and pharmocologically diverse compounds (McLaughlin, 1998). So, the second objective of our study was to correlate the cytotoxic potency of the extractives of $Q$. indica through brine shrimp mortality.

Quisqualis indica (Family - Combretaceae, Bengali name - Modhumaloti) is an evergreen creeping shrub, which can be as much as 70 feet long in tropical climates (Welsh, 1998). It is widely distributed in all districts of Bangladesh (Ghani, 2003). The leaves of $Q$. indica are opposite and $7-15 \mathrm{~cm}$ long. Its flowers have a faint sweet aroma and they bloom in the spring, early summer or mid fall (Welsh, 1998). Fruits of this plant are used to treat ascariasis and oxyuriasis (Beers, 1999), while the decoction of the fruit is useful in toothache and nephritis. The roasted ripe seeds are beneficial in diarrhoea, fever and rickets. Furthermore, seeds macerated in oil can also be applied in parasitic skin troubles (De Padua, 1999). Decoction of leaves is useful in abdominal pain and the leaf juice is a remedy for boils and ulcers. The leaves are also used to treat various kinds of infantile disorders and skin diseases, where as the roots are used in rheumatism and diarrhoea. Besides, the plant extract has been found to be anticoccidial for veterinary purposes (Youn and Noh, 2001). Previous phytochemical studies with the $Q$. indica led to the isolation of quisquagenin, quisqualic acid, quisqualin $\mathrm{A}$ and quisqualin $\mathrm{B}$ (Dictionary of natural products, 2002). In this paper, we report the preliminary antimicrobial activity and cytotoxicity of $Q$. indica extractives for the first time.

\section{MATERIALS AND METHODS}

\section{Plant materials}

Stem bark of $Q$. indica was collected from Dhaka in August 2006 and was identified at the Department of Botany, University of Dhaka. The clean bark was cut into small pieces and air-dried for several days. The pieces were then oven dried for $24 \mathrm{~h}$ at $40^{\circ} \mathrm{C}$ and ground into a coarse powder.

\section{Extraction}

The powdered bark $(750 \mathrm{~g})$ of $Q$. indica was soaked in $1.5 \mathrm{~L}$ of methanol for 7 days and then filtered through a cotton plug followed by Whatman filter paper number 1 . The extract was concentrated with a rotary evaporator. A portion $(5 \mathrm{~g})$ of the concentrated methanol extract was fractionated by the modified Kupchan partitioning method (Vanwagenen et al., 1993) into $n$-hexane, carbon tetrachloride, chloroform and aqueous soluble fractions. Subsequent evaporation of solvents afforded $n$-hexane $(1.50 \mathrm{~g})$, carbon tetrachloride $(1.25 \mathrm{~g})$, chloroform (1.00 g) and aqueous soluble $(1.10 \mathrm{~g})$ materials.

\section{Biological screenings}

\section{Antimicrobial assay}

The disc diffusion method (Bauer et al., 1966) was used to test antimicrobial activity of the extractives against twelve bacteria and three fungi (Table 1). Solutions of known concentration $(\mu \mathrm{g} / \mathrm{ml})$ of the test samples were made by dissolving measured amount of the samples in calculated volume of solvents. Dried and sterilized filter paper discs (6 mm diameter) were then impregnated with known amounts of the test substances using micropipette and the residual solvents were completely evaporated. Discs containing the test material were placed on nutrient agar medium uniformly seeded with the test microorganisms. Standard disc of kanamycin $(30 \mu \mathrm{g} /$ disc) and blank discs (impregnated with solvents followed by evaporation) were used as positive and negative control, respectively. 
Table 1. Antimicrobial activity $Q$. indica extractives at $400 \mu \mathrm{g} /$ disc

\begin{tabular}{lrrrrc}
\hline \multirow{2}{*}{ Test microorganisms } & \multicolumn{5}{c}{ Diameter of zone of inhibition (mm) } \\
\cline { 2 - 6 } Gram positive bacteria & HX & CT & CF & AQ & Kan \\
Bacillus cereus & $10.23 \pm 0.33$ & $15.16 \pm 1.14$ & $15.35 \pm 0.68$ & $15.41 \pm 0.33$ & $25.13 \pm 0.84$ \\
Bacillus megaterium & $15.19 \pm 0.24$ & $8.24 \pm 1.17$ & $20.22 \pm 0.94$ & $13.36 \pm 0.75$ & $30.21 \pm 0.61$ \\
Bacillus subtilis & $10.33 \pm 0.70$ & $14.26 \pm 0.28$ & $12.33 \pm 1.30$ & $16.28 \pm 0.73$ & $23.16 \pm 1.10$ \\
Staphylococcus aureus & $12.45 \pm 0.56$ & $15.48 \pm 0.33$ & $16.48 \pm 0.68$ & $12.26 \pm 0.67$ & $26.33 \pm 0.67$ \\
Sarcina lutea & $11.21 \pm 1.10$ & $15.26 \pm 0.15$ & $12.37 \pm 0.57$ & $14.30 \pm 0.77$ & $24.15 \pm 0.25$ \\
\hline Gram negative bacteria & & & & \\
Escherichia coli & - & $12.37 \pm 0.28$ & $15.65 \pm 0.91$ & $12.20 \pm 1.12$ & $22.31 \pm 0.34$ \\
Pseudomonas aeruginosa & $10.33 \pm 0.84$ & $11.45 \pm 0.31$ & $14.23 \pm 1.30$ & $13.33 \pm 1.10$ & $20.16 \pm 1.33$ \\
Salmonella paratyphi & $8.37 \pm 0.54$ & $10.13 \pm 1.24$ & $13.47 \pm 0.82$ & $12.32 \pm 2.12$ & $25.20 \pm 1.14$ \\
Salmonella typhi & $11.27 \pm 0.33$ & $17.41 \pm 0.98$ & $15.35 \pm 1.35$ & $14.26 \pm 0.62$ & $25.24 \pm 0.42$ \\
Shigella dysenteriae & $8.35 \pm 0.87$ & $10.33 \pm 1.32$ & $10.33 \pm 1.12$ & $11.18 \pm 0.69$ & $25.18 \pm 0.84$ \\
Vibrio mimicus & $15.11 \pm 1.11$ & $10.98 \pm 1.50$ & $20.21 \pm 1.24$ & $15.27 \pm 0.57$ & $28.17 \pm 0.70$ \\
Vibrio parahemolyticus & $12.34 \pm 0.24$ & $16.40 \pm 0.89$ & $16.41 \pm 1.67$ & $11.11 \pm 0.37$ & $25.26 \pm 0.61$ \\
\hline Fungi & & & & \\
Candida albicans & $11.16 \pm 0.31$ & $14.15 \pm 0.56$ & $15.33 \pm 0.84$ & $13.33 \pm 1.39$ & $25.33 \pm 1.13$ \\
Aspergillus niger & $14.25 \pm 0.33$ & $18.23 \pm 0.29$ & $13.22 \pm 1.61$ & $10.12 \pm 1.14$ & $25.21 \pm 0.54$ \\
Sacharomyces cerevaceae & $08.24 \pm 0.35$ & $14.17 \pm 0.68$ & $12.11 \pm 1.33$ & $10.17 \pm 1.22$ & $20.27 \pm 0.57$ \\
\hline The diameters of zones of & &
\end{tabular}

The diameters of zones of inhibition are expressed as mean \pm S.D. $(\mathrm{n}=3)$; a diameter less than $8 \mathrm{~mm}$ was considered inactive; HX: $n$-hexane soluble fraction of the methanolic extract; CT: carbon tetrachloride soluble fraction of the methanolic extract; CF: chloroform soluble fraction of the methanolic extract; AQ: Aqueous fraction of the methanolic extract; Kan: standard kanamycin $(30 \mu \mathrm{g} /$ disc $)$.

These plates were then kept at low temperature $\left(4^{\circ} \mathrm{C}\right)$ for $24 \mathrm{~h}$ to allow maximum diffusion. There was a gradual change of test materials concentration in the media surrounding the discs. The plates were then incubated at $37^{\circ} \mathrm{C}$ for $24 \mathrm{~h}$ to allow maximum growth of the organisms. The test material having antimicrobial activity inhibited the growth of the microorganisms and a clear, distinct zone of inhibition was visualized surrounding the medium. The antimicrobial activity of the test agents was determined by measuring the diameter of zone of inhibition expressed in millimeter. The experiment was carried out in triplicate.

\section{Cytotoxicity study}

Brine shrimp lethality bioassay (Persoone, 1980; Meyer et al., 1982; McLaughlin et al., 1998) technique was applied for the determination of cytotoxic property of the plant extractives.

\section{Preparation of positive control group}

Vincristine sulphate was used as the positive control. Measured amount of vincristine sulphate was dissolved in DMSO to get an initial concentration of $20 \mu \mathrm{g} / \mathrm{ml}$ from which serial dilutions were made using DMSO to get $10 \mu \mathrm{g} /$ $\mathrm{ml}, 5 \mu \mathrm{g} / \mathrm{ml}, 2.5 \mu \mathrm{g} / \mathrm{ml}, 1.25 \mu \mathrm{g} / \mathrm{ml}, 0.625 \mu \mathrm{g} /$ $\mathrm{ml}, 0.3125 \mu \mathrm{g} / \mathrm{ml}, 0.15625 \mu \mathrm{g} / \mathrm{ml}, 0.078125 \mu \mathrm{g} /$ $\mathrm{ml}, 0.0390 \mu \mathrm{g} / \mathrm{ml}$. Then the solutions were added to the premarked vials containing ten live brine shrimp nauplii in $5 \mathrm{ml}$ simulated sea water.

\section{Preparation of negative control group}

$100 \mu \mathrm{l}$ of DMSO was added to each of three premarked glass vials containing $5 \mathrm{ml}$ of simulated sea water and 10 shrimp nauplii. If the brine shrimps in these vials show a rapid mortality, then the test is considered as invalid as the nauplii died due to 
some reasons other than the cytotoxicity of the compounds.

\section{Preparation of test groups}

$4 \mathrm{mg}$ of each of the partitionates obtained by Kupchan fractionation was dissolved in DMSO and solutions of varying concentrations such as $400,200,100,50,25,12.50,6.25,3.125,1.563$ and $0.781 \mu \mathrm{g} / \mathrm{ml}$ were obtained by serial dilution technique. Then the solutions were added to the premarked vials containing ten live brine shrimp nauplii in $5 \mathrm{ml}$ simulated sea water.

\section{Counting of nauplii}

After $24 \mathrm{~h}$, the vials were inspected using a magnifying glass and the number of survived nauplii in each vial was counted. From this data, the percent $(\%)$ of lethality of the brine shrimp nauplii was calculated for each concentration. The median lethal concentration $\left(\mathrm{LC}_{50}\right)$ of the test samples was obtained by a plot of percentage of the shrimps killed against the logarithm of the sample concentration.

\section{Statistical analysis}

For each of the extracts, three samples were prepared for each of the bioassays. The zone of inhibition and $\mathrm{LC}_{50}$ were calculated as mean \pm S.D. $(n=3)$ for the antimicrobial screening and brine shrimp lethality bioassay, respectively.

\section{RESULTS}

The extractives of $Q$. indica demonstrated varying degrees of inhibition to growth of microorganisms and strong cytotoxic activity against $A$. salina. The $n$-hexane, carbon tetrachloride, chloroform and aqueous soluble fractions of the methanolic extract were subjected to screening for inhibition of microbial growth against 12 bacteria and 3 fungal strains. Table 1 represents the summary of the antimicrobial activity of the samples with respect to each of the test organisms. The average zones of
Table 2. $\mathrm{LC}_{50}$ data of test samples of $Q$. indica

\begin{tabular}{cc}
\hline Samples & $\mathrm{LC}_{50}(\mu \mathrm{g} / \mathrm{ml})$ \\
\hline VS & $0.200 \pm 0.11$ \\
$\mathrm{HX}$ & $1.254 \pm 1.33$ \\
$\mathrm{CT}$ & $0.826 \pm 0.26$ \\
$\mathrm{CF}$ & $3.866 \pm 1.25$ \\
$\mathrm{AQ}$ & $5.366 \pm 1.33$ \\
\hline
\end{tabular}

The values of $\mathrm{LC}_{50}$ are expressed as mean \pm S.D. $(n=3)$. VS: vincristine sulphate (Std.); HX: $n$-hexane soluble fraction of the methanolic extract; CT: carbontetrachloride soluble fraction of the methanolic extract; CF: chloroform soluble fraction of the methanolic extract; AQ: aqueous fraction of the methanolic extract.

inhibition produced by the $n$-hexane, carbon tetrachloride, chloroform and aqueous soluble fractions of the methanolic extract were found to be 8 - $15 \mathrm{~mm}, 8-18 \mathrm{~mm}, 12-20 \mathrm{~mm}$ and $10-16 \mathrm{~mm}$, respectively. On the other hand, the cytotoxcity of the samples was evaluated against Artemia salina (Table 2) where significant effects were demonstrated by the $n$-hexane, carbon tetrachloride, chloroform and aqueous soluble fractions of the crude methanol extract with $\mathrm{LC}_{50}$ values of $1.254,0.826$, 3.866 and $5.366 \mu \mathrm{g} / \mathrm{ml}$, respectively.

\section{DISCUSSION}

In the antimicrobial susceptibility test by the disc diffusion method, the chloroform soluble material demonstrated the highest inhibitory activity in the present screening at a dose $400 \mu \mathrm{g} /$ disc. It showed the strongest activity against $V$. mimicus and $B$. megaterium having the zone size of 20.21 and 20.22 $\mathrm{mm}$, respectively. The growth of $S$. aureus $(16.48$ $\mathrm{mm})$, V. parahemolyticus $(16.41 \mathrm{~mm})$, E. coli $(15.65$ $\mathrm{mm})$, B. cereus $(15.35 \mathrm{~mm})$, S. typhi $(15.35 \mathrm{~mm})$ and P. aeruginosa $(14.23 \mathrm{~mm})$ was also strongly inhibited whereas moderate activity was found against $S$. paratyphi $(13.47 \mathrm{~mm})$, S. lutea $(12.37 \mathrm{~mm})$ and $B$. subtilis $(12.33 \mathrm{~mm})$. Among the fungi, the growth of C. albicans was strongly inhibited with zone size $15.33 \mathrm{~mm}$. The growth of A. niger $(13.22 \mathrm{~mm})$ and S. cerevaceae $(12.11 \mathrm{~mm})$ was moderately inhibited. 
At the same time, the carbon tetrachloride partitionate of the methanolic extract showed significant inhibitory activity against $S$. typhi having zone of inhibition $17.41 \mathrm{~mm}$. The growth of $V$. parahemolyticus $(16.40 \mathrm{~mm})$, S. aureus $(15.48 \mathrm{~mm})$, S. lutea $(15.26 \mathrm{~mm})$, B. cereus $(15.16 \mathrm{~mm})$ and B. subtilis $(14.26 \mathrm{~mm})$ was also inhibited significantly. In addition, it showed moderate inhibition of growth of E. coli $(12.37 \mathrm{~mm})$, $V$. mimicus $(10.98 \mathrm{~mm})$ and $P$. aeruginosa $(11.45$ $\mathrm{mm})$. In case of fungi, the growth of $A$. niger was strongly inhibited $(18.23 \mathrm{~mm})$ by this extractive while the growth of $C$. albicans and S. cerevaceae was also inhibited with zones of inhibition of 14.15 and $14.17 \mathrm{~mm}$, respectively. The aqueous soluble materials of the methanolic extract of $Q$. indica showed moderate to strong activity against the tested microorganisms. The growth of B. subtilis (16.28 $\mathrm{mm}$ ) was strongly inhibited. It also showed similar activity against $B$. cereus $(15.41 \mathrm{~mm}), V$. mimicus $(15.27 \mathrm{~mm})$, S. lutea $(14.30 \mathrm{~mm})$ and S. typhi $(14.26 \mathrm{~mm})$. Moderate activity was found against B. megaterium (13.36 mm), S. aureus (12.26 mm), E. coli $(12.20 \mathrm{~mm})$ and S. paratyphi (12.32 $\mathrm{mm})$. At the same time, mild to moderate inhibition $(10-13 \mathrm{~mm})$ was found against the tested fungi by the extractive.

Following the procedure of Meyer et al. (1982) the lethality of $n$-hexane (HX), carbon tetrachloride (CT), chloroform (CF) and aqueous soluble partitionates (AQ) of the methanolic extract to brine shrimps was determined. The degree of lethality was found to be directly proportional to the concentration of the extract ranging from the lowest concentration $(0.781 \mu \mathrm{g} / \mathrm{ml})$ to the highest concentration $(400 \mu \mathrm{g} /$ $\mathrm{ml})$. The $\mathrm{LC}_{50}$ obtained from the best-fit line slope when the mortality of shrimp was plotted against the concentration of the sample were $0.200,1.254$, $0.826,3.866$ and $5.366 \mu \mathrm{g} / \mathrm{ml}$ for positive control (vincristine sulphate), HX, CT, CF and $\mathrm{AQ}$, respectively. In comparison with positive control, the cytotoxicity exhibited by the carbon tetrachloride and hexane soluble fraction of methanolic extract was promising.

The significant antimicrobial activity of the chloroform, carbon tetrachloride and aqueous soluble fractions of the crude methanol extract against a wide range of pathological microbial species and strong cytotoxicity of the $n$-hexane, chloroform, carbon tetrachloride and aqueous soluble fractions of the methanolic extract against brine shrimp support the traditional uses of $Q$. indica as a remedial agent.

\section{ACKNOWLEDGEMENTS}

We wish to thank the Ministry of Science and Information \& Communication Technology, Government of the Peoples' Republic of Bangladesh for partial financial support to carry out the research.

\section{REFERENCES}

Bauer AW, Kirby WMM, Sherris JC, Turck M. (1966) Antibiotic susceptibility testing by a standardized single disc method. Am. J. Clin. Pathol. 45, 493-496.

Beers MH, Berkow R. (1999) The Merck Manual of Diagnosis and Therapy, Section 13, Chapter 161, Whitehouse Station, NJ: Merck Research Laboratories.

De Padua LS, Bunyapraphatsara N, Lemmens RHMJ. (1999) Plant Resources of South-East Asia No. 12 (1): Medicinal and Poisonous Plants 1. Source Backhuys Publications, Leiden, the Netherlands, pp. 711.

Dictionary of Natural Products, Chapman and Hall, 2002.

Ghani A. (2003) Medicinal plants of Bangladesh, Chemical constituents and uses, Asiatic Society of Bangladesh, Dhaka, $2^{\text {nd }}$ edition, pp. 363.

Karaman I, Sahin F, Güllüce M, Öigütçü H, Sengül M, Adýgüzel A. (2003) Antimicrobial activity of aqueous and methanol extracts of Juniperus oxycedrus L. J. Ethnopharmacol. 85, 231-235.

McLaughlin JL, Rogers LL. (1998) The use of biological assays to evaluate botanicals. Drug $\operatorname{Inf}$. J. 32, 513-524.

Meyer BN, Ferrigni NR, Putnam JE, Jacobsen JB, Nicholsand DE, Mclaughlin JL. (1982) Brine shrimp: a convenient general bioassay for active plant constituents. Planta Med. 45, 31-34.

Persoone G. (1980) Proceeding of the international 
symposium on brine shrimp, Artemia salina, pp. 1-3, University Press.

Rahman S, Hasan CM, Rashid MA, Ilias M. (2001) Pharmacological evaluation of Bangladeshi medicinal plants - a review. Pharm. Biol. 39, 1-6.

Ram AJ, Bhakshu LM, Raju RRV. (2004) In vitro antimicrobial activity of certain medicinal plants from Eastern Ghats, India, used for skin diseases. J. Ethnopharmacol. 90, 353-357.

Rashid MA, Hasan CM, Choudhury SAR, Begum B, Rahman S. (1997) Ethnopharmacological investigation of medicinal plants of Bangladesh. Bangladesh J.
Physiol. Pharmacol. 12, 25-29.

Vanwagenen BC, Larsen R, Cardellina, JH II, Randazzo D, Lidert ZC, Swithenbank C. (1993) Ulosantoin, a potent insecticide from the sponge Ulosa ruetzleri. J. Org. Chem. 58, 335-337.

Welsh SL. (1998) Flora Societensis: A summary revision of the flowering plants of the Society Islands. E.P.S. Inc., Orem, Utah, p. 64.

Youn HJ, Noh JW. (2001) Screening of the anticoccidial effects of herb extracts against Eimeria tenella. Vet. Parasitol. 96, 257-263. 